\title{
Chefia e Liderança
}

\author{
José de Almeida Rios \\ Professor da Universidade do Brasil, Diretor \\ da Seção de Segurança Nacional do Minis- \\ tério da Educação e Cultura
}

\section{CONCEITUAÇÃo}

$\mathrm{D}$ ADis as diversidades de organização de emprêsas, os sistemas governamentais nunca iguais, apesar de obedecerem a certos fundamentos doutrinários, às características de administração, especialmente no domínio oficial torna-se difícil conceituar ortodo-) xamente o que seja chefia e liderança. Contudo, em bases gerais e doutrinárias, será possivel um pensamento uniforme ao identificarmos os dois têrmos como uma capacitação para influenciar outras pessoas quando grupadas, definindo em conjunto um esfôrço coordenado para persegtiir objetivos comuns passando por finalidade. Desde logo verificamos que certos atributos e qualidades, positivus e negativos que permanecem no individuo e prevalentes de sua fase primária instintiva, obriga a que um chefe e um lider necessitem ter habilidade para conduzi-los, discipliná-los e conjugá-los objetivando a realização de uma tarefa. Assim, pois, em que pese o avanço da tecnologia, que é ciência, técnica e organização, acessivel a atialquer que tenha capacidade prevalente para aprendê-la, alguma coisa mais existe que é uma capacitação segmentária a que chamariamos "Vocação". Isto, nada mais representa do que a arte de chefiar e dirigir.

Poderemcs pela técnica conseguir atualmente formar um chefe em um senti to administrativo, levando-se em conta atribuições e responsabilidades limitadas que o levam quase a uma atuação individual na hierarquia da expedição de ordens e de diretrizes. Contudo, já o lider tem que se haver com o pensamento e a ação coletivos. Aqui a técnica sòmente não poderá formá-lo. Ele tem que possuir qualidades prevalentes. A predominância da arte é indiscutivel. Duvidosa seria a "autenticidade". Se êle tem 
"que influenciar e dirigir homens" é preciso, para conseguir um resultado favorável ao bem coletivo, que esteja corretamente informadn e consciente das condições, situações, aspirações e interêsses de seu grupo. Um lider que procura definir-se pela opinião coletiva de seu grupo com linalidade de "promoção pessoal", visando posições é um falso "lider". Muito comum em nosso tempo os "falsoz lideres", entre escritores e jornalistas.

Chefiar e dirigir nâo significam apenas expedir, ordens e fazer com que sejami cumpridas.

Chefiar é:

- influenciar;

- sugestioniar cooperação;

- convencer co-responsabilidade de tarefas;

- demonstrar as vantagens do trabalho em equipe;

- provar a importáncia da tarefa de cada qual.

No conceito dé executar, chefiar é: prever, prover, coordenar e controlar que é igual a planejamento. As diversas denominações que em vários paises são empregadas para designar atribuições de chefia, ocorren justamente pela diversidade de métodos e organizações existentes. Cada têrmo define um campo diferente de atribuições e de responsabilidades.

Diretor, Chefe, Superintendente, Gerente, Supervision, management, são todos postos de chefia, variando, porém, o campo e os limites de atribuiçôes e responsabilidades. Assim, management, tanto se refere nos E.U.A. a um Chefe de emprêsa, ou de serviços de um hotel, como a um treinador de boxe. No mesmo raciocinio o mestre tanto se refere a um cientista, como a um professor primário ou chefe de oficina. Não podemos aqui detalhar e definir os campos de atribuições e de responsabilidades das terminologias acima mencionadas.

A escolha de um chefe geralmente está ligada a uma política geral da emprêsa onde um "maior interêsse", qual seja aquêle de seiecionar certo, esteja em jôgo. Em todos os setores de atividades e em todos os paises vigora tal critério "pervertido" de seleção. Nas grandes emprêsas, especialmente aquelas de grande competição coniercial, geralmente para postos de chefia executiva em escalões periféricos o processo é correto. Um chefe precisa ter um senso especial de análise e de crítica. A inteligência seria a qualificação mais importante.

Via de regra en um grupo de trabalho a fisionomia do chefe se desenha espontâneamente no seu meio. Assim, a eleição ou escolha por aclamação pelos companheiros seria um método aconselhável. Esta posiçăn natural adquirida já daria ao chefe apoio 
quanto a autoriclade e a elevação moral do grupo, dois elementos importantes para o sucesso da execução das tarefas. E' muito difícil o critério de avaliação do mérito. Um excelente funcionário poderá ser um péssimo Chefe.

Um Chefe precisa ter boa cultural geral, conhecimento teórico das tarefas a cargo do grupo, integridade moral e coragem de atitude. O equilibrio entre autoridade e sentimento é importante. Dai decorre saber conquistar a estima (sentimento), mas gozar também do respeito (integridade moral) de seus companheiros. Na sua formação técnica, além da cultura geral indispensável, deverá conhecer as operações particulares a que seus companheiros sảo obrigados. Deve, geralmente, mandar fazer o que sabe fazer. Precisa desenvolver o senso natural que possui acêrıa dos subsicios científicos trazidos pelas ciências, especialmente a psicologia social e a sociologia. Tem que integrar-se nos principios de relações humanas, especialmente no que se refere a relações internas.

\section{QUALIFICAÇÃo}

Tomar um ponto de partida para formar ou melhorar as condições de chefia, envidando esforços para aperfeiçoá-la e desenvolvê-la, parece-nos do maior interêsse da era Tecnológica que atravessamos. Para Fayol os requisitos seriam os seguintes:

A - saúde e vigor físico;

B - inteligência e valor intelectual;

C - qualidades morais: vontade refletida, firme, perseverante; ativiuade, energia e, quando necessário, coragem; coragem das responsabilidades; sentimento do dever, cuidado com o interêsse geral;

D - forte cultura geral:

$\mathrm{E}$ - capacidade administrativa, compreendendo:

a) previdência - habilidade em traçar e fazer traçar o proçrama de ação;

b) organização - em particular, saber constituir o corps social;

c) comando - arte de manejar os homens;

d) courdenação - harmonizar os atos, fazer convergir os esforços;

e) contrôle:

F - noç̃os gerais sôbre tôdas as funções essenciais da emprêsa; 
G -. maior competência possivel na atividade especial característica da einprêsa.

Em um "Curso de Supervisão e Gerência de Serviços" organizado pelo Professor Wagner Estelita Campos, no Departamento Administrativo do Serviço Público, procedeu o referido técnico a um inquérito entre 67 alunos, onde se encontravam, alguns chefes. O resultado foi o seguinte:
A - intelị̣̂nencia
$\mathrm{B}$ - energia fisica e nervosa
- 61 indicações
C - integridade moral
$-60$
$\mathrm{D}$ - equiidade
E - iniciativa
F - capacidade técnica
$-48$
G - cultura geral
$-45$
$-43$
$\mathrm{H}$ - lealdade
I - cordialidaće e afeição
$-42$
$-41$
$\mathrm{J}$ - entusiasmo
$-40$
$\mathrm{K}$ - capacidade administrativa
$-39$
$\mathrm{L}$ - autoconfiança
$-36$
$-34$
$-29$
M - bom humor
$-28$
$\mathrm{N}$ - conhecimento de natureza humana
$\mathrm{O}$ - energia
$\mathrm{P}$ - decisão
$-27$
$\mathrm{Q}$ - coragem

Realmente se sintetizarmos tais resultados em três significados, acreditamos ter acertado. Pela inteligência, pela capacidade técnica e pela energia física e nervosa (saúde), abrangemos tôdas as demais exigencias. $E^{\prime}$ bem verdade que a inteligência tem que ser disciplinada pela "vocação" de chefia. A inteligência já induz - desejo de possuir boa cultura geral, demonstrar integridade moral, equiidade, iniciativa, lealdade, cordialidade, entusiasmo, bom humor e conhecimento de natureza humana. A capacidade técnica engloba a capacidade administrativa, a psicologia social e relações humanas, etc. A saúde, sobretudo na esfera psicológica, auxilia no contrôle e na obediência aos preceitos da técnica de contato com outros homens. A injustiça funcional constitui um dos pontos que mais comprometem a moral do chefe. Não poderemos analisar cada uma das qualidades, classificando-as, procurando defini-las ou conceituá-las, nas sintéticas considerações do presente trabalho. Contudo, é preciso ressaltar que em direção e Superintendência, por exemplo, algumas qualidades seriam mais 
importantes que no sentido de Chefia, que em princípio seria uma fase executiva das operaçôes. Nesta, os atributos prevalentes, ligados estreitamente ao problema de relações humanas, adquirem importància maior. Neste caso, o equilibrio entre autoridade e sentimento deve fazer $\sim$ se sentir com mais relevância.

\section{ATRIBUIÇÕES E RESPONSÅBILIDADES}

Em sintese o Chefe tem que ter qualificação suficiente para saber elaborar um Planejamento. Previsão e Provisão são dois vocabulos que congregam o pensamento de executar bem, conjugando, coordenando, avaliando e aplicando aquelas qualificações inerentes e adquiridas já mencionadas. Contudo, particularizando, enumeremos as seguintes:

a) análise e critica da ou das tarefas a serem executadas, sua execiüibilidade frente aos meios disponiveis;

b) adaptação dos planos e programas, assim como as tarefas aos meios disponiveis;

c) seleção dos meios e recursos - material e pessoal;

d) planejamento de execıção -- distribuição das tarefas já avaliadas de acôrdo com os meios materiais disponiveis e a cap̉acidade cie cada quual.

A Direção poderá já ter feito o Planejamento e transmite ao Chefe a tarefa de execução por Diretrizes seguras, claras e precisas, onde já devem ter sido avaliados os meios disponiveis conforme as finalidades e objetivos a serem atingidos. Contudo, compete ao Chefe, dentro de sua responsabilidade, ao fazer seu Planejamento de execução, elaborar uma revisão de particularização, das Diretrizes recebidas para executar. O Chefe consciente de sua responsabilidade deve levar ao conhecimento do Diretor hierárquico, muitas vêzes em caráter reservado, a impossibilidade (inexeqüibilidade) de perseguir as finalidades e objetivos das Diretrizes recebidas com os meios de que dispõe. Assim atuando, transfere parte de sua responsabilidade ao escalão superior.

O Cheie deve estabelecer uma hierarquia de prioridades na distribuição de seu tempo, de acôrdo com sua Política Adminis trativa ou conforme as necessidades e imprevistos, ligados ou não a revisões. São ações correspondentes geralmente ao Contrôle e decorrentes da Fiscalização.

Para FAYOL as cinco atribuições do Chefe são as seguintes:

a) Organização - "constitui o duplo organismo material e social de uma emprêsa";

b) Comando - "fazer funcionar o pessoal"; 
e) Coordenação - "unir, harmonizar todos os atos e todos os esforços";

d) Contrôle - "fazer com que tudo se execute na conformidade das regras estabelecidas e das ordens dadas".

Devendo o Chefe possuir as qualidades de um planejador, considerando-se o Planejamento como - Prover e Prever - tem que cumprir as demais qualificações ligadas à fase de exeçução onde pela Org̣anizaçẫo, lida com outros homens. Já o prover e prever implica em "avaliar" os recursos disponiveis. A Organização deve dispor de elementos materiais e humanos para tarefas determinadas. Sem a "provisão" proporcional nenhum Chefe poderá ter capacidade de organizar. Na própria organização situa-se a Fiscalização e o Contrôle, obedecendo a normas técnicas conhecidas.

Luthier Gulik valeu-se da palavra "POSDCORB" para sintetiza: os têrmos "administração e gerência" do seguinte modo:

P - lanning (planejamento);

$\mathrm{O}$ - rganizing (organização);

S - taffing (administração de pessoal);

D - irecting (direção, comando);

$\mathrm{CO}$ - ordinating (coordenação);

R -- eporting (publicidade, documentação, informação propaganda);

B - vdgeting (elaboração, execução e fiscalização orçamentária).

Alfred M. Cooper, com uma grande experiência de Direção e Adtainistração, condensa sua opinião sôbre as responsabilidades do Chefe, do seguinte modo:

a) responsabilidade pela efetividade da produção;

b) responsabilidade pela segurança, saúde e condições físicas dos subordinados;

c) responsabilidade pela formação e desenvolvimento da moral cio grupo;

d) responsabilidade pela cooperação com os superiores, colegas de direçâo e os próprios subordinados; tórios;

e) resporısabilidade pela manutenção dos registros e rela-

E. W. SMITH resume sua opinião em três itens:
a) planejamento;
b) execução;
c) contrôle. 


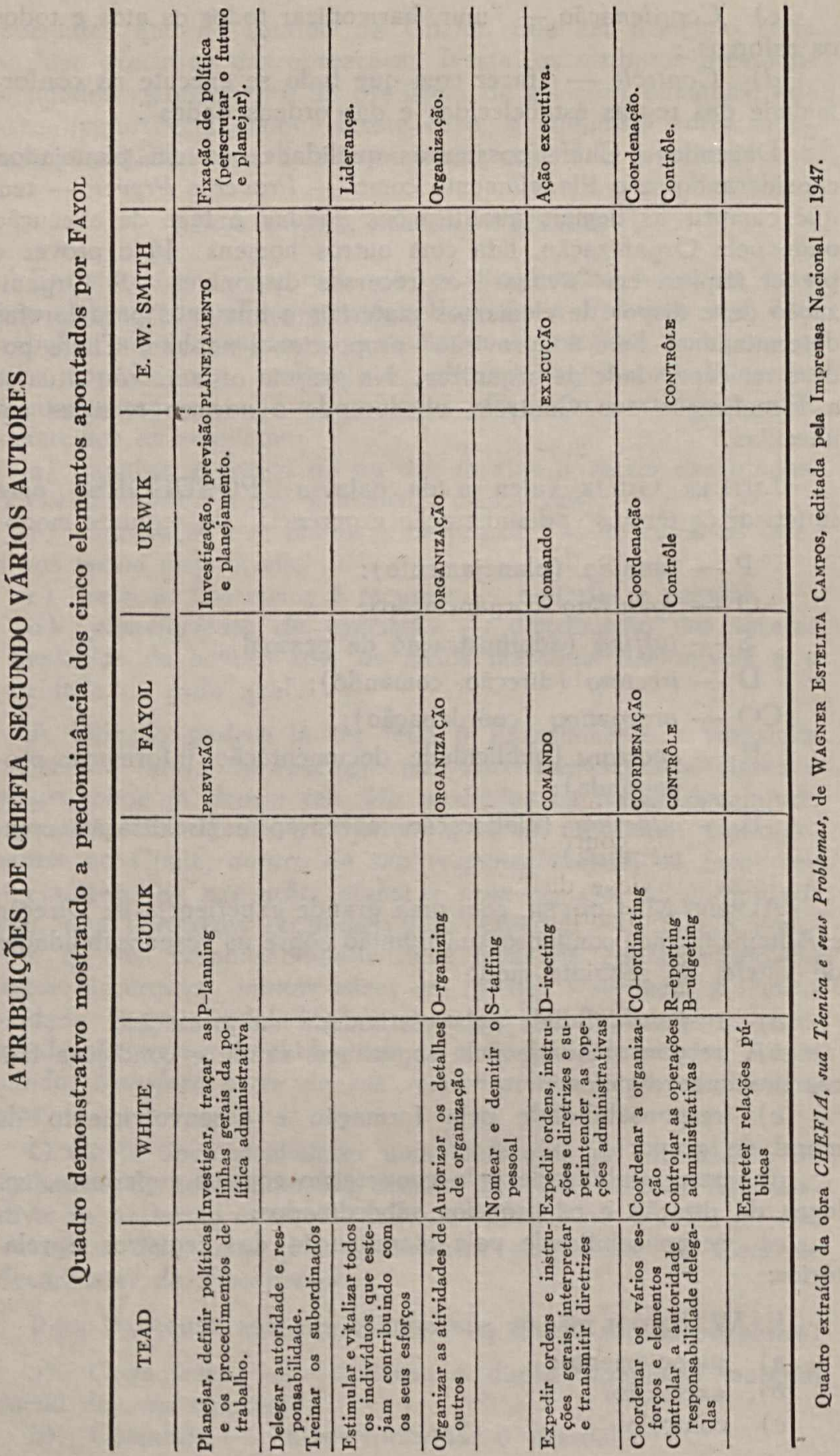


AÇÃo

TEAD observa que a direção, como tôda "arte", tem suas "técnicas", a que chamamos mais pròpriamente "táticas", para que sejam obtidos bons resultados. Enumera o mesmo autor as seguintes atitudes "técnicas":

- expedição de ordens;

-.- repreensão;

- elogio;

- rranutenção de uma atitude pessoal correta;

- obtenção de sugestões;

- fortalecimento do sentimento de identidade do grupo;

- cuidados na apresentação ao grupo;

- criação da disciplina própria do grupo;

- afastamento de "falsos rumôres".

$\mathrm{Na}$ expedição de ordens, TEAD manda observar o seguinte:

a - ser claro;

$b$ - ser explícito;

c - usar um tom de voz adequado;

$d$ - empregar frases corteses;

e - evitar ordens simultâneas;

$t$ - reduzir ao minimo as ordens negativas e evitar as ordens contraditórias.

O Chefe deve distinguir bem entre "dirigir" e "comandar". O primeiro está intimamente identificado com consentimento e o outro com obediência. No inglês encontramos dois têrmos: to lead e to boss. Verificamos exata semelhança entre atuação de Estado Democráticr e Estado Autoritário. O cidadão no primeiro caso faz parte de uma Instituição que constitui "um meio para servir ao Estado, isto é o govêrno". O Chefe deve convencer que o grupo congrega esforços obietivando o interêsse da coletividade. No "comando" resulta a ação do Chefe identificada como uma "coação". Mesmo quanto ao cumprimento de um dever que deve ser "convencionado" como uma obrigação social, tal forma de levar os individuos a cumprirem sua "tarefa" social, não resultará em efeitos definitivos e leais. Quando se apresentar a opnttunidade de "reação", esta se manifesta sob as mais variadas formas. Não está formada a união de pensamento, mesmo que na aparência haja uniformidade de atitude. A chefia democrática exige um esfôrço consentido "pelo dever" e não uma "coação para o dever". Na filosofia democrática o Chefe exerce 
a autoridade "com seus subordinados" e no sentido autoritário "sôbre seus subordinados". A atitude da chefia deverá ser aquela que incute a seus subordinados o pensamento de que êles são responsáveis pela posição do grupo írente a outros grupos, no que respeita a conceito e prestígio moral.

Na expedição de ordens é preciso considerar que a "mecânica da organização" já estabelecida, estando bem fundamentada na distribuição de tarefas e responsabilidades, raramente deve exigir ordens "diferentes". A atitude de quem dá ordens deverá tomar características impessoais, definindo-se e identificando-se com uma rotina funcional. O uso do imperativo deve ser abolido como formula gramatical de expedir uma ordem. Tôda clareza e rigor devem ser usades no emprêgo dos vocábulos, fugindo sempre ao critério de utilizar "têrmos excepcionais" quanto à prática de linguagem. Salvo tm questões técnicas, em que a terminologia tem que ser precisa, o "usual" tem que ser "corriqueiro", porém correto. E' prejudicial ao senso de moral do Chefe as maneiras e manifestações pedantes. Naturalidade e segurança deverão ser as atitudes frente aos subordinados. As ordens negativas impressionan mal ao senso moral do grupo, não devendo revestir-se de uma "negação rígida", senão sob forma de sugestão. Outra atitude negativa é a expedição de ordens simultâneas, a un mesıo funcionário. As objeções funcionais ou observações feitas ao Chefe no ato de êste dar uma ordem devem ser ouvidas com a melhor atenção.

A repreensão e o elogio constituem dois pontos de excepcional delicadeza. Em principio, nunca uma repreensão deverá ser pública ou com testemunhos. Após a sua efetivação, a atitude do Chefe deverá permanecer exatamente a mesma. Coritudo, nunca a repreensão, e em conseqüência a punição, deverãc ser umpostas sem a precisa investigação prévia de possiveis condições - situações particulares que possam ter alterado o humor e a atitude funcionais; se necessária, deverá ser serena, demonstrar uma ação funcional e nunca pessoal, e, sendo possível, deixada para uma oportunidade além do fato provocador. Muito boa conduta seria aguardar um favor ou dispensa solicitada pelo funcionário, quando se poderia concedê-los e fazer referència ao fato passivel de repreensão.

O elogio sòmente será cabivel quando decorrente de atuação fora do limite regulamentac. Deverá, ao contrário da repreensâo, ter ampla divulgação e ser de modo ostensivo. Um elogio imerecido constitui uma das piores formas de "perversão" à "justiça funcional". Na insubordinação, em que, sem irritação as "medidas corretivas" devem ser prontas e imediatas, o Chefe saberá 
evitá-las ou pelo menos a sua ostensividade (ordens parti.:ulares), para investigar possireis impactos humorais prevalentes do funcionário. Age aqui com ênfase a "tática" de equilibrar autoridade e sentimento. O grupo, via de regra, está a par daquelas motivações pessoais que estejam alterando o humor de un! companheiro.

O Chele tem qire atender a quaisquer sugestões e observa. çoes, demonstrando o maior interêsse e insistindo para que o funcirnnário vá ao gabinete para melhores esclarecirientos. As objeções do Chếe não devem ser públicas, resguardando-se para fazê-las de modo "particular". Nesta ocasião, procure semp̣re dar razão ao subordinado, objetando contudo quanto a dificuldades que ultrapassam as possibilidades de ambos. A posição hierárquica já coloca o Chefe frente ao subordinado em condições de motivação por complexo. Quando se apresentar a oportunidade de seguir ou atender, no todo ou em parte a sugestão, deverá pùblicamente comunicar-lhe, com audiência de seus colegas. A vaidade constitui ur atributo inerente ao gênero humano, manifestando-se inclusive pela modéstia premeditada. No trato com os homens, imbuidos de conhecimento de psicologia social, é preciso lançar mão dos fatôres positivos e também dos negativos da natureza humana. Ambas representam grandes fôrças de realização. Umm dos pontos mais delicados para compor a atitude de um Chefe é a identificação correta do complexo de cada qual. Um dos mais freqüientes é aquêle da ignorância que se manifesta pela tencência de "saber e explicar tudo", e encontrar sempre uma "objeção" a qualquer idéia ou procedimento nôvo. Mais se manifestà tal disposição quando ela parte de um colega, sobretudo daquele que tem merecido do Chefe incumbências mais importantes. E' preciso, contudo, afastar do raciocínio mencionado, aquêles que mantêm apurado senso de análise e crítica, vocação evidente de cientista e pesquisador, não aproveitada convenientemente. A diferença logo se nota quando, neste caso, são exigidas pelo analisado, excepcionais detalhes, minúcias e exposição mais correta. O complexado, pelo contrário, contenta-se com exposições rápidas e sucintas, com receio que descubram ou desconfiem de uma capacidade que pretende possuir. Na luta competitiva moderna agigantou-se o problema do complexo, refletindo condições e falbas personalíssimas, que um Chefe deve saber conhecer para corrigir ou adotar atitudes adequadas. Quanto mais alto na escala burocrática mais freqüentemente se encontram tais disturções pessoais nas autoridades. Tal qualificação tem a maior utilidade para o trato do Chefe com autoridades de hierarquia superior.

A moral e a disciplina de grupo estão na dependência da ação do Chefe e de sua "tática" de equilibrar a autoridade com 
o sentimento. Em verdade as qualidades do Chefe formam um conjunto sincrônico e conjugado visando aos resultados de trabalho da equipe. E' indispensável dar consciência ao grupo de "sua unidade" e da importância da tarefa individual no funcionamento do conjunto. Para TEAD, a disciplina é "a ordenação e contrôle de procedimento individual e coletivo de maneira que facilite a consecução de alguns propósitos definidos". No diagnóstico, para o qual deve haver o contrôle, decorrente da fiscalização, nunca um Chefc deve dar ou deixar suspeitar de que atua ou atuou por espionagem e delação. Procurará demonstrar "ter sentido" a indisciplina, se por acaso não chegou a testemunhá-la. Naturalmente, a advertância, a repreensão ou punição, devem ser atos de naturalidade e como já frisamos, se possivel, levada a efeito fora da ocasião em que se deu a falta. Fora as causas individuais já mencionadas, poderá haver necessidades de um dignóstico da moral e da disciplina do conjunto, quase sempre revelada por atuação individual. O moral do grupo é elevado quando o subordinado mostra disposições para cumprir tarefas fora e além da rotina e dos regulamentos. A isto se denomina interêsse. Fal tando certa predisposição de "dar mais um pouco" do que lhe compete, já se pode suspeitar de falta de integração na "unidade" de trabalho. Influem muito as condições favoráveis para que sejam cumpridas as tarefas. As dificuldades materiais, quando o moral é elevado, são vencidos com ânimo e desenvoltura. Para Cooper três são os fatôres que influem decisivamente na formação e desenvolvimento do moral:

a) interêsse do subordinada pelo serviço;

b) satisfação com as condições de trabalho;

c) qualidades de direção, demonstrada pelo chefe.

1) ajustamento à função é de especial importância. Integrado na. "importância" de sua tarefa individual, precisa o subordinado ter condiçöes eficientes de "orgulhar-se" do trabalho realizado. Compete ao chefe orientar o treinamento, estimular constantemente e encontrar motivos especiais e particulares para enaltecer a tarefa funcional. Os principais sinais de insatisfação são os seguintes:

- mudança de humor;

- excesso de erros ou enganos;

-. irritabilidade;

-- preocupação;

- intensificação de ausência e desinterêsse pelo trabalho;

- acidentes mais freqüentes;

- demonstração de fadiga fácil etc. 
A ação do chefe, divorciada dos princípios fundamentais que regem o assunto, poderá resultar na indisciplina e na baixa do moral do grupo. No inquérito procedido por WAGNER EsteLITA Campos, no curso em que foi coordenador e já citado, o resultado entre 51 alunos foi o seguinte:

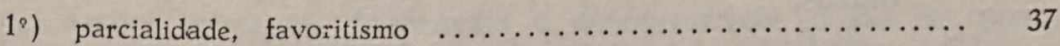

$\left.2^{\circ}\right)$ rispidez, mau humor $\ldots \ldots \ldots \ldots \ldots \ldots \ldots \ldots \ldots \ldots \ldots \ldots \ldots \ldots \ldots \ldots, \quad 35$

$3^{\circ}$ ) tendência autocrática (intransigência, autoritarismo, intolerância,

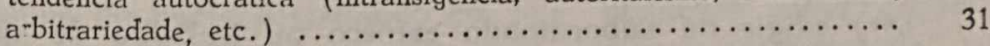

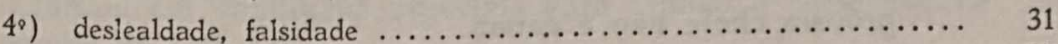

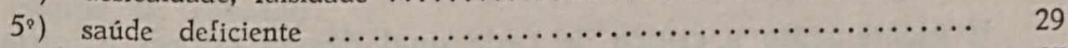

6*) incompetência (desconhecimento do serviço) . .............. 27

7 ) desinterêsse, desânimo falta de entusiasmo ................. 21

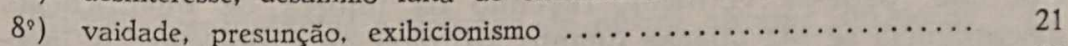

92) inacessibjlidade, falta de espírito de cooperação ............. 20

10²) displicência, indolència .............................. 19

$\left.1^{\circ}\right)$ indecisão, falta de autoconfiança $\ldots \ldots \ldots \ldots \ldots \ldots \ldots \ldots \ldots \ldots \ldots \ldots$

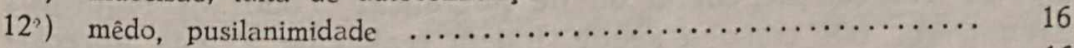

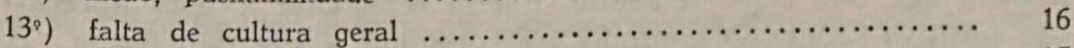

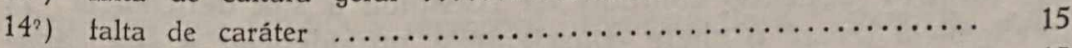

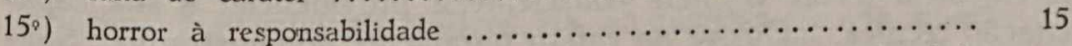

$\left.16^{\circ}\right)$ incapacidade de manter a disciplina, falta de energia, bondade

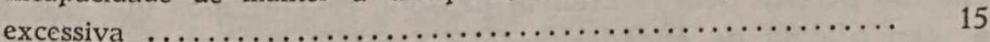

170) inconsistência, incoerência ............................ 13

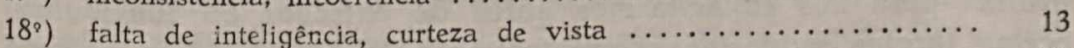

19॰) inveja dos subordinados ............................... 12

$2^{\circ}$ ) ausência de noçãa de responsabilidade .................... 11

$\left.21^{\circ}\right)$ impaciência, falta de autocont:ôle $\ldots \ldots \ldots \ldots \ldots \ldots \ldots \ldots \ldots, 11$

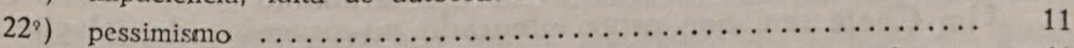

23.) desconfiança dos subordinados, incapacidade em delegar atribuições 11

$\left.24^{\circ}\right)$ falta de compostura, linguagem de "giria" ............... 10

$\left.25^{\circ}\right)$ incapacidade administrativa $\ldots \ldots \ldots \ldots \ldots \ldots \ldots \ldots \ldots \ldots, 10$

$\left.26^{\circ}\right)$ não reconhecer valor nos subordinados $\ldots \ldots \ldots \ldots \ldots \ldots \ldots, 10$

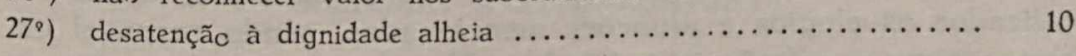

O Professor Wagner Estelita Campos em sua experiênca anota os seguintes:

19) rispidez, mau humor;

2.) tendência autocrática;

3) falta de inteligência;

4.) inveja dos subordinados;

$\left.5^{\circ}\right)$ receio de ser ofuscado pelos subordinados;

$\left.6^{\circ}\right)$ incapacidade administrativa;

7) teimosia, irredutibilidade de opiniôes; 
8.) relutância em delegar atribuições;

9:) falta de estímulo ao esfôrço dos subordinados;

$\left.10^{\circ}\right)$ "apropriação indébita" do esfôrço alheio;

11\%) julgamento "apressado" dos subordinados, uns perante outros;

12.) protelação sistemática de resoluções;

13.) subserviência para com os superiores;

$1^{\circ}$ ) exigir de subordinado esfôrço ou trabalho de que o próprio chefe não é capaz.

Evidentemente a crítica de cada qual dêsses fatôres exigiria uma longa tarefa ultrapassando os limites do presente trabalho. Contudo, pode-se verificar, revendo os fatôres de qualificação, discordància se faz apenas quanto à ordem de exposição. A inteligência ou sua falta nos parece uma das mais importantes qualificações. Dela decorre a "tática" que é arte, desde que haja alguma vocação de chefia ou de liderança. Todos os requisitos irrecutiveis, tais como a saúde, fogem realmente a uma apreciação positiva. podendo contudo ser corrigida a sua deficiência. A inteligência levará o chefe consciente a providenciar a sua capacitação técnica, inclusive na esfera puramente administrativa. Solicitando perdão pela referência pessoal, revelaremos que nós fomos a uma oficina de encadernação e a outra de "técnica de mimeo grafia" para nos capacitarmos antes de entregar ao funcionário certas tarefas modestas referentes ao assunto. Foi um esfôrço para tentar cumprir uma tarefa de chefia em que nos encontramos ainda.

Um Chefe tem que estar integrado no processo de relações humanas. A sua tarefa começa já no primeiro contato quando da apresentação do subalterno. O próprio chefe deverá fazer as apresentaçũes, tendo tido o cuidado de se informar das atividades anteriores do mesmo. Na "conversa" de apresentação seriam focalizados os elogios e atuações mencionados, sendo razoável em certos cascs a referência à família. Número de membros, tempo de casado, responsabilidades decorrentes, o caminho do homem seguindo a meta de evolução e de desenvolvimento social etc. Via de regra, para atuação mais direta nas atividades de relações humanas especificamente naquela de relações internas, um número favorável de subordinados seria de 25. (American Management Ảssuciationi, Set. 1944). Um fichário de relações internas deverá estar sempre em dia ao alcance da consulta do chefe ou de seu assessor. A familia deve estar integrada na responsabilidade do funcionário ou empregado. Resguardando a necessidade de equilibrio entre autoridade e sentimento, para justamente fortalecer o 
espirito de disciplina, os acontecimentos familiares, as vicissitudes, as dificuldades, os problemas da familia de um subordinado devem fazer parte da politica administrativa de um chefe. Ao mesmo tempo, as manifestações afetivas, os aniversários, as comemorações familiares precisam ter o conhecimento do chefe para que, en ambos os casos, favoráveis e desfavoráveis, possa êle tomar parte. A sua atuação "prestativa" nas dificuldades familiares "integra" a família no que respeita à responsabilidade funcional. O tempo do chefe despendido em tais "pequenas manifestações" resultan em vantagens especiais para "união e uniformidade" na equipe de trabalho.

As relações internas devem ultrapassar os muros da dependência administrativa, devendo o fichário mencionado conter indicações e referências a colegas de outras chefias, diretores e superiores. Na estrutura do caráter brasileiro vamos encontrar o "sentimento" como uma das características mais fortes. Assim sendo, torna-se importante o papel do chefe em saber fazer funcionar o mecanismo de "relações internas". A "cooperação" com seus subordinados e com os superiores decorre da politica administrativa que facilita a recíproca, despertando o "interêsse" pelos serviços. Naturalmente reflete ela a qualificação de chefia em suas variadas formas. Para despertar "interêsse" o chefe deverá ser o primeiro a demonstrar atitude adequada.

A fiscalização e o contrôle estão integrados na organização. A ação respectiva deve tomar "caracteristicas funcionais e rotineiras" fuģindo ao critério de espionagem e delação. Ulm Chefe nunca deverá colocar um subordinado na posição de delator. Mesmo tendo conhecimento da identidade do faltoso não deve externá-lo e, muito menos tomar medidas repreensivas ou punitivas. Precisa conseguir que o próprio faltoso se identifique. Em uma rotina de tarefa distribuida, torna-se fácil o problema.

\section{REUNIÕES E AÇÃO CONJUNTA}

As reuniões para debater objetivos de serviço constituem uma boa "politica" de conseguir "unidade" do grupo. De preferência devem ser escolhidas as "reuniões sem formalidade". Porém, muitas vêzes há indicação para certo grau de formalismo, sendo utilizada a "mesa-redonda". Nesta o chefe preside à reunião. Geralmente trata-se de assunto técnico, novas idéias, pontos a retificar na rotina do serviço, interpretação de novas diretrizes recebidas de escalóes superiores etc. Quando existe uma variedade de assuntos, alguns membros podem discutir separadamente e acertar os pontos controvertidos. Volta-se então a constituir a "mesa-redonda" para apreciação geral. Esta forma de reunião 
admite o auditório em volta de uma mesa, podendo haver participação nas discussões "em igualdade de condições". Nesta modalidade de reunião não há preparativos prévios. Teòricamente não haverá Presidente, contudo, é comum a orientação dos trabalhos e a abertura de reunião feitas pelo chefe.

$\mathrm{Na}$ "discussão sem formalismo", a reunião é geralmente "dominada" por um lider, para discussão de um problema. O chefe senta-se com o grupo e não existe a formalidade de pedir a palavra. Não existe dissertação sôbre matéria preparada com antecedência, nem perguntas prèviamente elaboradas. $O$ pressuposto é que o líder (não o chefe) tenha algum objetivo definido para a discussão e que a conduzirá neste sentido. Tais reuniões são eficazes para desembaraçar e despertar as "vocações" de liderança ainda inibidas. O Chefe tem que se colocar em absolut a igualdade de condições, explicando mesmo que ali a sua "qualidade e autoridade do Chefe" desapareceram. O grupo de discussão sem formalismo tem larga variedade de usos, desde as discussões preparatórias (Conferências), subgrupos ligados por idéias e pensamentos semelhantes, elaboração de temas para Comissões de certo vulto, conquista de outros subgrupos para uniformizarem idéias conciliáveis etc. Servem para reuniões preparatórias, "não oficiais".

\section{DIREÇÃO DE COMISSÕES}

Depende muito da habilidade dn Presidente o encaminhamento favorável das discussões até chegar a um ponto conciliatório que possa fundamentar uma conclusão unânime ou de grande maioria. Poderemos deduzir que a Inglaterra é administrada por Comissões que assessoram eficientemente todos os atos públicos. A grande vantagem da Comissão é englobar uma certa variedade de pontos-de-vista diferentes, o que vai de encontro aos problemas que nem sempre apresentam a simplicidade superficial com que se revelam.

Entre outros, as Comissões apresentam os seguintes aspectos positivos:

1ค) obter a cooperação de outros grupos e indivíduos;

$\left.2^{\circ}\right)$ promover a compreensão do problema encarado por uma entidade;

$\left.3^{\circ}\right)$ prover centros de interpretação de trabalho de uma entidade;

4.) melhorar o trabalho de uma entidade por meio de discussões construtivas; 
5\%) provar a validade das idéias de secretário executivo;

60) proporcionar contato entre o elemento executivo da entidade e os membros da comunidade com os quais é preciso trabalhar:

7॰) promover ação coordenada com resultado de decisões tomadas en conjunto;

8) oferecer uma oportunidade aos leigos de trabalho eficiente numa entidade profissional.

Uma Comissão pode ser: Consultiva ou Executiva. As espécies variam, podendo ser de Planejamento, de Direção, de Investigaçñes, de Inquérito etc.

O tamanho está ligado aos principais interêsses e pontos-devista, variando de 5 a 20 membros. Sendo deliberativa, quanto menor o número maior facilidade de acôrdos.

\section{QUALIFICAÇÃO DOS MEMBROS}

$1^{\text {a) }}$ devem ser pessoas interessadas no assunto;

2:; podem ser pessoas a quem se queira interessar;

$3^{\text {? }) ~ p e s s o a s ~ i n f l u e n t e s ~ n a ~ c o m u n i d a d e ; ~}$

$\left.4^{a}\right)$ devem encarar o problema de um ponto-de-vista; mesmo contrariando aquêle do secretário, deve ser apresentado.

\section{PAPEL DO PRESIDENTE}

Sua função principal é manter a Comissão trabalhando regular e uniformemente na tarefa que lhe foi confiada. As atividades seguintes esquematizam seu papel:

13) deve conhecer o assunto;

23) preside, abre e encerra as reunióes;

3:) mantém a ordem, evita digressões irrelevantes etc.;

$4^{\text {a) }}$ proporciona oportunidade de apresentação de todos os pontos-de-vista:

$5^{\text {a) }}$ deve ser imparcial;

$6^{a}$ ) fazer perguntas pertinentes visando à clareza da discussão;

7*; ajudar a Comissão a chegar a conclusões.

Resumindo, um Presidente tem a obrigação de conseguir um alto nivel de discussões, adiar questões muito controvertidas para ajustamento (reuniões sem formalidade), encaminhar bem as discussões, aparar com inteligência aparentes divergências, dar o 
exemplo de respeito à opinião de cada membro, devendo conseguir pelas discussões uma uniformidade de idéias e de decisões, que seriam impossiveis sem essa interação de pensamento e de personalidades.

Uma agenda deve ser distribuida a todos os membros. A distribuição dos assuntos deve obedecer a um esquema que coloque no meio de tempo calculado da reunião as questões mais relevantes. Aquelas de deliberações fáceis e já assentadas constituern as primeiras, deixando para a última fase dos trabalhos aquelas que exigiram deliberação mais demoradas.

O Secretário - Geralmente se mantém em segundo plano. Procura estimular a responsabilidade, a apresentação de idéias e a atividade dos membros. Assiste o Presidente com suas sugestões. Não deve participar ativamente até o momento em que é solicitado a fornecer informações. Deve expor claramente as informações pedidas assim como dar a sua opinião.

Contorme a espécie e o tipo de Comissão, muitas vêzes ela é obrigada a "interpretar as Diretrizes recebidas" para saber qual ou quais os objetivos a serem perseguidos. Deve, se fôr o caso, interpretar o texto da Lei ou de Regulamento frente aos assuntos ou problemas que tem de decidir. Será útil um "sumário provisório" para a fase de investigações e contatos, coleta de documentos, ordem prioritária de importância ou de necessidade, de acôrdo com as discussões e divisão dos pontos a serem focalizados. Tal "sumário" com uma identificação do número de cada capitulo ou divisão, facilitará a triagem e a manipulação, assim como organizará o "rascunho" do Relatório final. Após conseguir "interpretar" a Diretriz ou o objetivo a ser atingido, a Comissão estabelece um calendário para os trabalhos, deixando uma "boa margem de segurança" para apresentar o Relatório. O tempo maior será despendido com pesquisas, coleta de documentos e discussões. A distribuição de tarefas entre os membros, inclusive em pequenos grupos, não deve impedir qute tôda a Comissão tome conhecimento e discuta em conjunto.

Se uma Comissão dispãe de 60 dias, por exemplo, para apresentar seu Relatório distribuirá o temọo do seguinte modo:

1s) um dia (uma reuniâo) ou três dias para "interpretar a Diretriz" e providenciar novas instruções;

2\%) 40 dias para fosquısas, coleta de dccumentos e esclarzcimentos (palestras iesımunbas, contatos é...). Discussões: nal);

3) 10 dias pa:a o Ralatório (reuniões tinais e redaçăo ti-

4.) ate \& dias para segurança. 
Podem ser designados relatores parciais, conforme a amplitude do trabalho, dievendo contudo o "conjunto da Comissăo" tomar conhecumento e discutir. O relatório parcial é para facilitar a coordenaçäo de matéria muito volumosa e dividir as tarefas de estudar, analisar e criticar mninúcias.

\section{LIDERANÇA DE DISCUSSÕES}

Un: líder deve tvitar fazer afirmações para colocar o grupo à vontade para iniciar o "processo" de expor e discutir. Com perguntas e afirmações sôbre assuntos doutrinários, poderá encaminhar e focalizar o problema em tela. Êle já deve ter estudado o assunto e, inclusive, guardado algumas soluçóes para expor. A exposição tem que ser ampla e abranger todos os ângulos e pontos controvertidos, com os argumentos enunciados em caráter de absoluta imparcialidade. As normas seguintes podem orientar o procedimento de um líder:

$1^{\text {a }) ~ o ~ l i ́ d e r ~ a p r e s e n t a ~ o ~ p r o b l e m a ~ d e ~ u m ~ m o d o ~ c l a r o, ~ c o m-~}$ pleto e preciso. anclisando e criticando tôda a argumentação pró e contra: fatos;

$2^{\text {a) }}$ fazer perguntas pertinentes, trazendo à luz todos os

$3^{\text {a) }}$ encorajar a apresentação dos diversos pontos-de-vista;

4) esclarecer as opiniões;

5a) distinguir e ajudar os outros a identificar os conflitos de atiudes e interpretaçöes errôneas das afirmativas enunciadas;

69) tentar discriminar as diferenças de mais e de menos importância que podem mais fàcilmente ser removidas;

$7^{\text {a) }}$ procurar com tato desencorajar as digressões;

8 ) manter a discussão em terreno impessoal;

9:) encaminhar a discussão para formulação final de uma solução;

10:) sunariar de vez em quando o progresso da discussão de modo a facilitar o seu desenvolvimento;

11) perceber o momento oportuno de terminar uma discussão e formular uma solução integrada;

\section{PRECAUÇÕES ESPECIAIS}

O líder deve penetrar as razões mais profundas que se escondem atrás das diferenças superficialmente expressas.

Não permitir que a argumentação sôbre os detalhes obscureça as considerações de maior importância. 
Ajudar os membros a pensar com clareza.

Economizar tempo solucionando questões já decididas, cuja procrastinação dos debates pode comprometer o progresso das discussões.

Atentar para a precisão exata das palavras, muitas vêzes usadas para significados diferentes

Não deixar o grupo enganar-se com "chavões" utilizados por leigos e políticos ignorantes ou demagogos. Muito comum é "renda justa" - "um nível de vida civilizado" - "reformas de base", etc.

Nas dúvidas ligadas à semântica de vocábulos, questões curriculares etc. recorrer a especialistas ou compêndios.

Evitar as situaçôes emocionais que possam "carregar" o ambiente. Para isso deverá prèviamente ter reajustado situações, convencionado atitudes e "persuadindo" procedimentos nas dis. cussões a se iniciarem, como uma profilaxia efetiva e eficiente.

Quando houver "dureza" em uma opinião que esteja entravando o progresso das discussões, o ponto poderá ser adiado, de preferência após um intervalo para uma "discussão informal". Chama a atenção para a necessidade de compreensão, caso contrário estará comprometida "tôda a Comissão".

O lider deve evitar as alusões, "alfinetadas" e insinuações, especialmente ligadas a motivos "pessoais". Procura "proteger" o atingido e "joga" o assunto para o campo impessoal, mostrando a "qualidade" de cada qual, que traz a responsabilidade quanto à cortesia e urbanidade.

Em caso de alterações mais violentas que firam "o programa disciplinar", inicia o lider a sumarização e chama a si a resposta.

\section{QUALIFICAÇÃO PARA UM LÍDER}

a) conhecimento de assunto;

b) habituado a técnicas de discussão;

c) conhecer o tipo de auditório e de seus interêsses, o motivo das respectivas presenças: observação, interêsse pessoal, participação ou simples assistência;

d) deve ter tato para chamar os tímidos à discussão, manter boa disposição entre os membros;

e) jovialidade, senso de humor, entusiasmo, respeito e acataniento a opiniões (especialmente políticas e crenças). 


\section{ELABORAÇÃO DE RELATÓRIO}

Um Relatório, conforme a amplitude e a diversificação do assunto, é uma tarefa de ação conjugada e coordenada. O Chefe assume a posição de um Coordenador. Em certos casos, cada Departamento, Setor ou Seção pode comportar um relatório particularizado de que o Chefe, na sua função, faz um extrato de análise, crítica e conclusão de cada um. Conforme a natureza dos Serviços e atribuições de um grupo, toma o relatório caracteristicas próprias, não deixando contudo de seguir um método mais ou tnenos igual. Em principio deverá obedecer à seguinte disposição:

a) Introdução ou histótico

Motivação e causas que deram lugar ao relatório; aí situam-se os dispositivos legais, as portarias, os memorandos, as ordens, fatos e acontecimentos etc.

b) $O$ método seguido na elaboração

Distribuição das tarefas de acôrdo com os setores, seções, e assuntos; disciplina das pesquisas e coleta de dados; justificação da conduta na exposição quanto a prioridade, importância e seqüência de assuntos; a ordem seguida etc.

c) Conclusões $\left({ }^{\star}\right)$

A conclusão deve ser sempre decisiva; pontos duvidosos serão analisados e criticados na "exposição" e referidos em "sugestões e recomendações".

d) Exposição

Poderá obedecer a uma ordem prioritária de importância ou de seqüência nosológica. Parece-nos mais racional o primeiro procedimento, sobretudo no que se refere a questões técnicas, salvo àquelas ligadas a documentos de contabilidade ou a prestação de contas. Nas Comissões de Inquérito, o fato tem que juntar-se ao

(*) Conciusões - Geralmente elas são colocadas no fim do relatório. Como, porém, os interessados e os escalões superiores pretendem verificar logo os resultados, (se positivos interessam menos como rotina administrativa) a sua colocação logo. após a Introdução ou Histórico, satisfaz imediatamente. Com tal disposição procura-se que a Direção tome contlecimento do Relatótio e de seus pontos mais importantes como sejam os aspectos negativos. Em administrações de elevado nivel técnico existem "Comissões de Revisão e de Contrôle", o que evita à Direção o exame de volumosos relatórios. Não é o caso brasileiro. 
documento de responsabilidade respectivo e numerados para referências na exposição. Nesta a análise e critica são destacadas de pontos, fatos ₹ documentos julgados mais importantes ou dignos de maiores esclarecimentos. Em se tratando de "inquérito", as fotocópias de páginas de livros e documentos originais são necessárias.

Em ıtm relatório merecem maior atenção os percalços, as dificuláades, as irregularidades e as deficiências observadas na ação de execução e sua repercussão nos resultados obtidos.

A grande utilidade de um relatório é corrigir para o futuro. Têm pois maior valor para o Chefe e os escalóes superiores de direção os elementos negativos do que os positivos. Eis por que devem ser realçados e mais bem criticados aquêles.

e) Recomendações e sugestões.

As recomendações procurarão corrigir e melhorar ao tentar afastar percalços, dificuldades, irregularidades e deficiências .

As sugestões se destinam a fazer progredir e desenvolver os serviços, assim como, trazer subsidios ao planejamento de sua expansão.

f) Agradecimentos e elogios

$\mathrm{O}$ agradecimento deve ser dirigido a grupos, chefes, funcionários e subordinados, que colaboraram com interêsse na execução das tarefas e dos serviços como no relatório.

O elogio, é difícil de conceituar e sua indicação, liga-se a um esforç̧o que tenha ultrapassado os deveres funcionais e o trabalho dedicado, identificado como de maior vulto do que um simples interêsse. Um funcionário que leva para casa uma parte ilustrativa (desenhos) de um relatório e sempre recusa compensações ligadas a prerrogativas funcionais e indenização material, merece o elogio. Tal atitude de chefe é uma das mais difíceis atribuições dado que sua indevida outorga poderá revelar uma injustiça funcional, uma das causas mais freqüentes de baixa de "moral do grupo".

\section{OUTRAS QUESTÕES}

O Planejamento de um Congresso, a elaboração de uma Conferência, de uma Palestra, a organização de um Seminário, a caracterização de um Painel e a formação de um Fôro sãu 
questões que deverão ser do conhecimento de um Chefe e de um Líder. Não poderemos no espaço restrito da presente exposição abordar as mesmas. Vamos, contudo, informá-las em anexos.

\section{BIBLIOGRAFIA}

TEAD, Ordway The Art of Leadership, McG:aw-Hill Book Co., N. Y. 1935. Cooper, Alfred M., How to supervise People, Mc. Graw-Hill Book Co., N. Y. 1941.

FAYOL, Henry, Administración Industrial y General, Trad. argentina, 1942, Ed. argentina de Finanzas y Administración.

Barnard, Chester I., The Functions of the Executive, Harward College, Cambridge, Mass. 1938.

САMPO3, Wagner Estelita, Chefia Imprensa Nacional - Brasil, 1947.

\section{ANEXO 1}

\section{CONGRESSO}

Um Congresso é um intercâmbio de informações, escoimadas das parcialidades geradas pela competição regional e local, no terreno científico e técnico. O intercâmbio deve ter a caracteristica da maior fidelidade no que respeita a resultados e conclusões, ressaltando-se com especial ênfase os aspectos negativos das experiências de cada grupo. Ai são afirmados os conceitos de "universalidade" das aquisições cientificas e técnicas. Um cientista, em principio, deve ser um escravo de sua Ética, e por ela fundamenta a sua personalidade de "homem da Humanidade". Não poderemos detalhar o Planejamento de um Congresso; contudo, informaremos as linhas básicas da organização.

Sintetizando, Planejar é: prever e prover.

Todo planejamento exige a análise e a crítica das Diretrizes, interpretando nelas os objetivos a serem perseguidos e as finalidades a serem atingidas. Muito racionalmente êles estão contidos e determinados pelos meios e recursos colocados à disposição, tanto no que respeita ao setor Administrativo, quanto ao Social e ao Técnico. Comumente existe a exigência de um prazo prévio minimo de 12 meses naqueles de natureza nacional e de 24 meses nos internacionais. Quando da proposta de localização, „já em Congresso anterior, como "encaminhamento" da votação "já deverão ser expostas fielmente as possibilidades" (meios e recursos), assegurados e balanceados, com os objetivos e finalidades. Assim, pois, o Planejamento, de um Congresso começa durante a realização do anterior (se fôt o caso). 
A Comissão Executiva, eleita no Congresso anterior, estabelece a Politica do futuro Congresso e expede as Diretrizes, que irão ter na Secretaria Geral (executiva) com sua secretaria. Aquela constitui o órgão centralizador e coordenador das "comunicações" e das "reações, e ligação com a Comissão Executiva.

Um "Corpo de Ligações" deverá ser imediatamente organizado na Secretaria Geral, para tomar conta de um grupo de participantes ou nacionalidades. Deverão estar bem informados acêrca de todos os pormenores e particularidades em seu "Centro de Coordenação" na Secretaria Geral. E' sempre aconselhável designar dois "ligações" - L-1 e L-2, não só para dividir atribuições conjugadas como para atender a imprevistos. O Ligação é a chave da fase de funcionamento de um Congresso. Uma mudança de programação poderá ser executada sem qualquer tropêço em algumas horas, mobilizando milhares de participantes. Nenhum participante ficará sem orientação no que deve ou pretende fazer. O "Ligação" deverá ser elemento de elevado nivel cultural, não sendo necessário um técnico. Várias Comissões serão organizadas; contudo, em principio, serão três: Técnicas, Administrativa e Social. Tôdas mantêm estreito e diário contato com a Secretaria Executiva. A primeira se compõe de "Setores", "Seções", "Assuntos" ou Temas. Na segunda encontraremos: inscrições, despesas, transportes, hospedagens e orientação. Conforme o vulto de participantes, tanto será suficiente um "encarregado" como um "escritório" ou "guichet". A terceira organizará a parte social, sendo comumente composta por Senhoras do Grupo hospedeiro. Disporá também de um "escritório ou guichet". Esta Comissão poderá dispor de "ligações", mas com atribuições apenas ligadas à mesma.

Os objetivos de um Congresso constam sempre de um intercâmbio de estudos e experiências visando assim "reajustar e revisar" condutas técnico-científicas, procurando uma linha de procedimentos mais correta na perseguição de uma "verdade cientifica e técnica", pelo menos na altura e no nivel em que se encontre o mais alto significado da cultura nacional ou universal. Ocorre logo que os temas escolhidos em um Congresso sejam aquêles que tenham impôsto maior interêsse científico e técnico, em referência a um juizo particularizado, ou que, pela sua amplitude, necessitem que se estabeleçam normas médias de procedimentos e conduta acordes com a conjuntura, condições, situações e imposições nacionais ou internacionais. As recomendações que devem constituir um dos epílogos são justamente para sincretizar os procedimentos permitindo menores possibilidades de êrro. Sendo decorrentes, muitas vêzes de conclusões. As suges- 
tões terão o objetivo de expandir os estudos e as experiências, levando subsidios adquiridos para encaminharem novos caminhos e novas direções.

Como finalidades o Congresso procura incentivar as relaçóes e a cordialidade que deve persistir e perdurar na "família cientifica e técnica universal ou nacional", assim como conquistar novas aquisições e intercâmbio sentimental solidificando e "unificando" laços cordiais, nas regiôes nacionais e nos países estrangeiros. Procura outrossim, elevar o nivel técnico e científico das profissões, provendo-o de maior aperfeiçoamento da Ética. Existem assim vantagens para a Humanidade, para o grupo social e para a profissão. Eis por que um govêrno que tem consciência de sua responsabilidade e demonstra interêsse real pela coletividade deve sempre prestigiar e incentivar a organização de Congressos. No mesmo passo poderemos raciocinar para aquêles grupos profissionais que mais de perto estejam ligados, como a classe hoteleira. Tendo a sua finalidade de conseguir lucros, deve estabelecer prioridade para os objetivos acima citados, se a tanto estiver consciente de sua responsabilidade de classe profissional de elite.

\section{ALGUNS DETALHES}

Alguns temas serão selecionados no Congresso anterior $e$ eleitos os Relatores. O relatório deve ser completo no histórico e na evolução; assim como na situação de "verdade" em que se encontra o assunto. Deverá conter alguma experiência do Relator. Contudo, uma sintese deverá ser lida, não podendo sua leitura exceder de 50 minutos. Os comentários não devem ultrapassar de dez minutos para cada participante. Um "Coordenador" de debates será designado para disciplinar e ordenar as intervenções, havendo necessidades de conseguir um outro elemento: o "Moderador", quando se prevejam debates agitados, extremados e muitas vêzes personalistas. Um Congresso deverá atender ao maior número de interêsses profissionais e técnicos dos participantes, com uma série de exposições e demonstrações de "Temas Livres". Nestes casos a discussão adquire caráter informal de uma discussão em grupo.

Para melhor ordenação a divisão em: Setor, Seção e Assuntos ou Temas facilita uma programação pessoal prévia de cada participante como torna menos árdua a tarefa dos "Ligações".

A parte Administrativa não apresenta qualquer dificuldade dado que as informaçóes e a aceitação já foram motivo de comunicações prévias da Secretaria Geral. Em caso de dúvidas, o 
"Ligação" ou o "escritório" conveniente resolverão fàcilmente. Geralmente durante o funcionamento as atividades ficam ai centralizadas.

A parte social tem também a sua Comissão, geralmente de Senhoras, com uma organização central e elementos de ligação que orientam um certo número de participantes.

Em linhas gerais é o que poderemos informar para que possa ser planejado em Congresso.

ORGANOGRAMA DE UM CONGRESSO

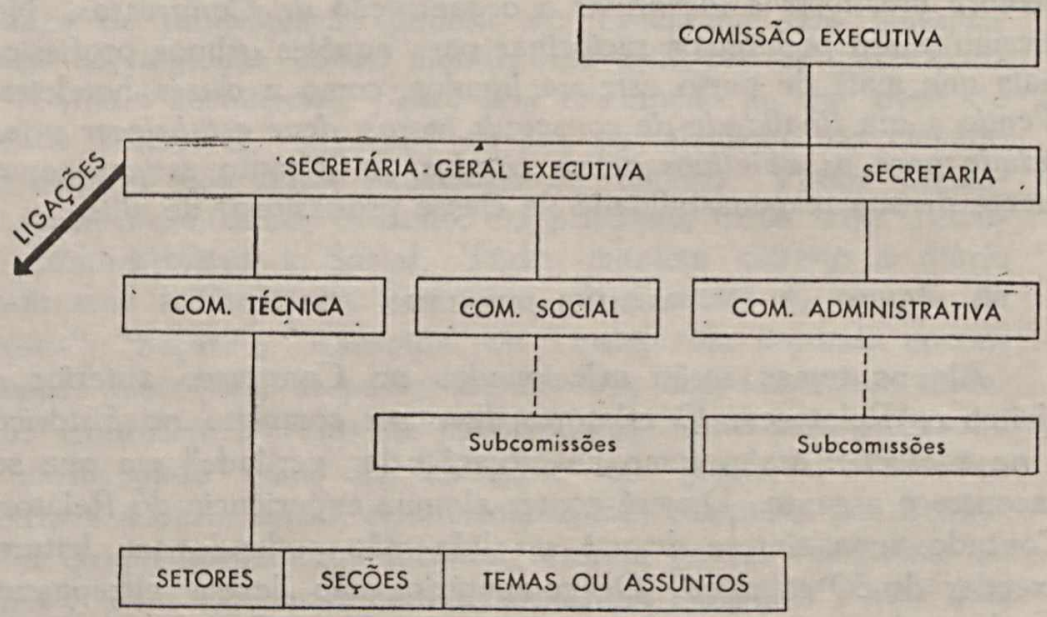

\section{BIBLIOGRAFIA}

Edward C. Lindemañ, Conference Method (Adult Education in Action) New York, George Grady Press, 1936, pág. 399-401.

EMERY S. Bogardus, Democracy by Discussion (Washington, D.C. American Council on Public Affairs) 1942, pág. 2-10.

Thomas Fansler, Discussion Methods for Adults Groups (New York J. J. Little and Ives Co.) 1934, pág. 1-56.

I. V. Garland and Charles F. Phillipe, Discussion Methods (New York, H. W. Wilson Co. 1940) pág. 161-193.

R. E. Dooler, A Fortum in a Village (Adult Education in Action) op. cit. pág. 278-280.

Eisie Gray Cambridge, An Institute in Rural Economics idem pág. 217-219. Eve Cappel, High School "Institutes", idem pp. 127-129 idem - "Labor Institutes" idem pág. 210-212. 
George Wilson Hobe, Trainning of the Job, idem pp. 164-167.

A. GraIG BaIrd, Discussion: Principles and Types (New York McGraw -Hill Book Co. Inc. 1943) pp. 197-208.

EMERY S. Bogardus, idem pp. 11-15.

Merse Adams Gartwright, Painel Discussion - Adult Education in Action - obra citada pp. 390-392.

THOMAS FANSLER, idem idem pp. 104.140.

J. V. Garland and Charles F. Phillips, idem idem pp. 108.111.

H. A. Overstreet, The Paintl as a Problem-solving Device, idem pp. 303-395.

William F. HIRTz, Planning a Meeting - reeditado de Los Angeles Couty Tuberculosis and Health Assoc. Trad. pelo A. (o maior subsidio do presente trabalho foi daqui extraido).

José de Almeida Rios, Uma Forma simples de Seminário.

\section{ANEXO 2}

\section{ELABURAÇÃO DE UMA CONFERENCIA}

E' muito comum a confusão entre Conferência e Palestra. Uma conferência é: um tipo de reunião destinada a grupos profissionais especificos ou a pessoas com identidade de interêsses, para consulta e elaboração de planos de trabalho. Aqui se encontra a diferença com Palestra.

Duas maneiras podem orientar o processamento de uma Conferência. Comumente gira a Conferência acêrca de um tema cu problema. Realizam -se reuniões gerais de acôrdo com o tema, seguindo se outras reuniôes, onde discussões e proposições são levadas e aprofundadas acêrca de pontos divergentes, contraditórios ou importantes.

Geralmente as Conferências são repetidas anualmente. Nas sessões plenárias são escolhidos o Presidente e os Presidentes das comissões gerais e especiais para o ano seguinte.

Outro modo, já mais simplicifado, resulta da apresentaçáo prévia de um Relatório, onde estejam metodizados a doutrina e os aspectos conjunturais (se fôr o caso). São selecionados grupos interessacios ou especializados para analisar e criticar os diversos pontos abordados no documento. O conferencista está obrigado a apontar a documentação de que se valeu para estabelecer novas ou pouco conhecidas afirmações ou negações, especialmente no que respeita a estatisticas. Quando os grupos selecionados comunicaram estar prontos para ouvir o Relator, apresentando por escrito, as objeções, as solicitações de esclarecimentos, como debates 
do próprio grupo ou pessoal: ou dispostos a debates verbais, será mercada a leitura. No dia aprazado serão convidados outros interessados, especialistas ou técnicos, que deverão debater no conjunto. O Relatório poderá ter o volume e a documentação qué fôr da disposição do Conferencista, não podendo contudo a leitura ultrapassar de 50 minutos. Raramente, quando terminar êste tempo, o Presidente da mesa poderá suspender a sessão por 15 minutos, concedendo mais 15 a 30 minutos de tolerância para exposição.

Geralmente a mesa inicia os debates para exemplificar a seqüência dos trabalhos. Um "Controlador" de tempo, notificando por sinais apropriados de advertência (luminosos, cigarra, campainha etc.), avisa que o tempo prèviamente anunciado de $5 \mathrm{mi}$ nutos para debatedores e 10 para o conferencista está a findar-se. O Presidente da mesa poderá delegar podêres de "Moderador dos debates, atribuições de sua competência. Os especialistas convidados também tomarão parte no debate, solicitando prèviamente ao Presidente uma maior concessão de tempo. Quando o conjunto, conferencista, participantes e especialistas convidados tomam parte no debate, transforma-se a Conferência em $\mathbf{u m}$ Painel.

Quando no correr dos trabalhos salientam-se ou enfatizam-se pontos diferentes da conferência, sobretudo quando o assunto não ficou suficientemente esclarecido, poderá a mesa destacar o tema para um futura organização de "Forum". Assim por exemplo: em uma conferência sôbre "Fundamentos Psicossociais do Poder Nacional", focaliz'u-se excepcionalmente a "influência do caráter nacional na formação politica". Dêste modo, o caráter nacional deveria tornar-se o tema para uma discussão "Forum".

\section{VANTAGENS}

Permite um grande número de participantes. Podem ser traçados planos de destaque para problemas atuais e oportunos. Deve seu uso ser limitado a grupos profissionais ou indivíduos com interêsse comuns dentro de assuntos determinados. Certos grupos estudiosos podem levar subsídios próprios, resultando em questões a serem ventiladas nas conferências futuras. Os resultados devem ser publicados e distribuídos entre os participantes.

Referências: EdWARd G. IJINDEMEN, Conference Method (Adult Education in Action) New York: George Grady Press, 1936. 
ANEXO 3

\section{ELABORAÇÃO DE UMA PALESTRA}

Em geral, o que ouvimos freqüentemente, e que rotulam como conferência, são palestras. Palestras é uma mensagem lida levada a um auditório interessado ou especialista por um outro interessado ou especialista. Uma palestra geralmente não deve ter pretensão de trazer assuntos ou pontos sujeitos a debates e controvérsias. O esclarecimento "do que quer dizer o orador", constitui a forma de debates. Via de regra, a palestra é uma súmula de conhecimentos acêrca de um tema ou assunto, contendo opiniões próprias do orador, se fôr o caso. A palestra é uma forma conveniente de sincretizar cultura entre niveis diversos, estabelecendo inclusive um intercâmbio, necessário para despertar outras iniciativas de maior profundidade e amplitude.

São ótimas as palestras para o intercâmbio universitário de professôres, estabelecendo uma "sincretização" de conhecimentos e iniciativas, podendo dai decorrer novas idéias de pesquisas e de trabalhos. Muito comum é a palestra acêrca de assunto "especializado" do orador, ou de experiência própria ou de técnica individual.

Assim pois, a palestra tanto pode constar de um assunto geral, do interêsse de um grupo, como de tema especializado para especialistas. Em verdade, ela representa a transmissão de um. pensamento próprio ou uma súmula de uma cultura representada pelo orador e referente ao tema em causa. Anotamos aqui a diferença existente entre conferência e palestra, confusão freqüentemente observada.

\section{ANEXO 4}

\section{FORUM}

E' uma forma de reunião na qual um especialista ou autoridade disserta sôbre assunto prèviamente determinado, seguindo-se discussão da qual os presentes podem participar.

\section{CARACTERÍSTICAS}

Um presidente abre os trabalhos, apresentando o orador e dirige a discussäo depois de terminada a exposição. Um ou dois oradores dissertam sôbre o assunto dado. Terminadas as exposições, dispõe o auditório de algum tempo para perguntas. 
VANTAGENS

A oportunidade para um número grande de pessoas ouvir um orador conceituado. Os presentes podem esclarecer pontos obscuros fazendo perguntas. $O$ orador pode apresentar seu trabalho sem digressão ou interrupções. Pode, assim, o orador desenvolver um tema ou tópico.

\section{DESVANTAGENS}

O orador fica limitado à apresentação e exposição de apenas um tema. No momento das perguntas, costuma-se pedir ao auditório que não se afaste do assunto. Há portanto pouco incentivo a ir além do exposto na formação de novas idéias.

Feqüentemente o auditório se divide em dois partidos durante a discussão: os que concordam e os que discordam do orador. Assim, ao invés de reunir conhecimentos e chegar a decisões novas a discussão degenera em perguntas pró e contra. Há relativamente poucas oportunidades para participação do auditório. As que aparecem são com freqüência monopolizadas pelos membros mais desembaraçados e agressivos.

\section{ASSUNTOS PARA FORUM}

Informes e análises recentes, interpretações de fatos conhecidos, esclarecimentos de pontos controvertidos e outras questões limitadas.

\section{TAMANHO DO AUDITÓRIO}

Limitado apenas pelas dimensões das salas de reunião e pelas condiçõe; de acústica. Quante maior o auditório menor o incentivo à participação.

\section{DIVERSOS}

Para combinarem-se as vantagens do Forum com a desejável participação de seus membros, sugere-se a divisão do auditódio em pequenos grupos de discussão. Após as discussões parciais todos se reúnem e são apresentados os relatórios do grupos menores ao grupo geral.

Com tal conduta assemelharse o Forum a uma conferência. Contudo, será possivel fazer a apresentação parcelar de grupos, com seus relatórios próprios, inclusive ao auditório geral, atendendo a perguntás ou esclarecimentos. Tomadas as notas respec- 
tivas, em tais reuniões prévias que seriam "Foruns Comuns", na reunião geral, qu己 poderá ter lugat dias após e que se chamaria "Forum Especial", seriam ampliadas as discussões e respondidas as perguntas e questões escritas (inclusive de grupos a outros grupos), sendo a mesa formada de comissóes ou representantes de cada grupo. Como cada um deverá ter um "Dirigente" e um "Relator", seriam principalmente êstes os representantes de seu grupo. Em linhas gerais tal conduta é seguida nos trabalhos internos da Escola Superior de Guerra, lançando-se mão outrossim do tipo "Conferência e Painel", em conjunto, com reais vantagens para que o auditório seja estimulado a novas idéias e novos pensanıentos. Muitas vêzes tal procedimento concorre para evolução dos processos e para despertar diretivas novas de estudos e de pesquisas. Com "Foruns Comuns" e "Forum Especial", podem as questões ser esclarecidas nos primeiros, reservando-se o seguinte para a seleção.

\section{Referências:}

EMERY S. Bogardus -- Democracy by Discussion (Washington, D. C. American Council on Public Affairs, 1942).

R. E. Dooley - A Forum in a Village - Adults Education in Action Loc. cit. pág. 278-280.

THOMAS FANSLER - Discussion Methods for Adults Groups (New York J. J. Little and Ives Co. 1934).

I. V. Garland and Charles F. Phillips - "Discussion Methods" (New York, H. W. Wilson Co. 1940).

\section{ANEXO 5}

\section{DISCUUSSAO EM PAINEL}

$E^{\prime}$ uma técnica educacional em que um grupo de especialistas discute, diante de um auditório, um problema sob diferentes pon. tos-de-vista. Após isso é permitida a participação do auditório na discussão geral. Uma Conferência ligada a questão de cultura geral, onde são focalizados e abordados pontos-de-vista variados no sentido técnico e científico, comumente é organizada sob forma mista - conferência-painel. Aliás é bastante comum tal condição quando o tema abordado não apresenta características especializadas, tanto científicas como técnicas. Constitui excelente. método para formação de elite quando se procura dar ao meio universitário uma base racional de cultura geral. O entrosamento de cientistas e técnicos é tão forte que o processo se transforma em um conjunto harnônico de "unidade", onde cadn qual mani- 
festa sua impressão, suas idéias e seu pensamento, a par de sel1 particular cabedal especializado. Ai fica patenteado que os problemas humanos não podem estar exclusivamente murados nas especializações; o que tem resultado para a Humanidade a evidente pobreza de elites dirigentes e de lideres autênticos. As conferências-painel deveriam tornar-se programas freqüentemente elaborados e executados nas universidades modernas.

\section{FiISTÓRICO}

O painel foi usado pela primeira vez em 1929, durante uma sessão de verão na UIniversidade de Califórnia, em Berkeley, por Harry A. Overstreet, do Colégio da cidade de New York. Mais tarde, êste método popularizou-se e foi denominado painel em uma reunião da Associação Americana para Educação de Adultos em maio de 1932 ("Planning a Metting" de William F. Hirtz).

\section{CARACTERÍSTICAS - PESSOAL}

Um presidente, um grupo de especialistas e o auditório.

\section{O AMBIENTE}

Todo o grupo de especialistas e o Presidente ficam sentados bem à vista do auditório, geralmente em um palco ou estrado. Na conferência-painel o ideal seria ficarem os especialistas, o Presidente, o "Coordenador" e o "Moderador" de debates e dis cussões (conforme a amplitude) situados na frente e lateralmente colocados, em relação ao auditório.

O Presidente apresenta o assunto, esquematizando os pontos importantes. Participa da discussão, controla e mantém o clima da reunião. No fim sumaria a discussão, conduzindo e orientando a participação do auditório. No final pode resumir o pensamento do grupo.

\section{ESPECIALISTAS}

Os membros do painel, geralmente de quatro a oito, são especialistas ou pessoas bem informadas sôbre certos aspectos do assunto em discussão. Discutem o problema livre e espontâneamente diante do auditório. Normalmente a discussão não é preparada com antecedência, embora os membros possam conhecer o objetivo e a amplitude com que deverá desenvolver-se a discussão. Não são usados discursos formais nem notas. 


\section{AUDITÓRIO}

Uma vez terminada a discussão mantida pelos membros dn painel, o auditório pode participar fazendo-lhes perguntas ou apresentando matéria nova.

\section{VANTAGENS}

Podem ser expressadas as opiniões e a experiência, de pessoas bem informadas, em vários campos de atividade. Diferentes pontos-de-vista podem ser apresentados. Há adequada oportunidade para a participação do auditório. Dentro de um grupo relativamente homogêneo, há excelente oportunidade para o desenvolvimento de concepçóes novas, resultantes de intercâmbio de idéias no grupo.

\section{DESVANTAGENS}

Há muita oportunidade para discussões sem importância, especialmente se a presidente não se mantém vigilante. A disposição do ambiente precisa ser satisfatória. $O$ descuido de não colocar todos os membros do painel perfeitamente visiveis entre si e para todos do auditóric conduz à distração, prejudicando a eficiência do painel. Há o perigo de os membros do painel não serem ouvidos por todo o auditório. Existe a falha de que o painel seja monopilzado por uma pessoa, criando assim uma apresentação especializacia do problema em discussão.

\section{MATERIAL MAIS ADEQUADO PARA PAINEL}

Assuntos de interêsse comum. Matérias de controvérsia. Temas em que seja desejável o desenvolvimento de novas idéias.

QUALIFICAÇÃO PARA PRESIDENTE E MEMBROS DO PAINEL

\section{Presidente}

O Presidente ou Lider deve ter conhecimento geral do assunto a ser discutido (não precisa ser um especialista). Como lider deve ser capaz de dirigir o curso da argumentação durante a discussão dos peritos, e depois, o concurso do auditório. Deve ter habilidade para conseguir a participação dos mais tímidos, contornar situações difíceis, capacidade para manejar discussões irrelevantes, aliando uma personalidade agradável e com senso de humor. 


\section{Membros}

Precisam conhecer e estar bem informados em algum aspecto do assunto, estando assim capacitados de contribuir. Devem discutir com serenidade e débater com segurança, mesmo emocionalmente comprometidos com alguma opinião ou técnica individual. Possuir contrôle para deixar a outros a oportunidade de participarem.

\section{Diversos}

O sistema de acústica tem grande importância, usando-se microfones móveis para atender aos participantes do auditório, nas organizaçñes mais bem providas. A gravação dos debates e discussões ainda formariam melhor fundamentação documentária e dariam maior responsabilidade nos debates e nas discussões.

() número de participantes deve ser de 50 a 200 , com boa homogeneidade cultural.

Referências:

A. Graig Baird Discussion: "Principles and Types" (New York, McGraw-Hill Co. Inc. 1943, págs. $197-208)$.

Emery S. Bogardus, loc. cit., pp. 11-15.

Morse Adams Cartwright Painel Discussion - Adult Education in Action ob. cit. págs. 390-392.

ThOMAS FANSLER, ob. cit., págs. 104-140.

J. V. Garland and Charles F. Phillips ob cot. págs. 108-111.

H. A. OverstreEt The Painel as a Problem-Solvind Devices - Adult Education in Action ob. cit. págs. 393-395.

\section{ANEXO 6}

\section{SIMPÓSIO}

E' um recurso através do qual se apresentam a um auditório aspectos diferentes o11 especiais de um determinado problema. Vários oradores podem expor o assunto, com preparo prévio e escrito. Assin: os detalhes em excesso e aspectos irrelevantes podem prejudicar a interferência do auditório.

\section{CARACTERÍSTICAS}

Presidente

Apresenta o assunto e os oradores, resumindo cada exposição quandis o orador termina. No fim resume tôdas as informações dadas. 


\section{Oradores}

São geralmente especialistas em algum aspecto do problema ou tópico da discussão. O trabalho comumente é prèviamente preparado.

\section{Auditório}

Após todos os discursos, o auditório tem oportunidade de participar.

Duração

Geralmente é de uma hora e meia.

$$
\text { AYัALIAÇÃo }
$$

Aspectos positivos

O problema em discussão pode ser apresentado de modo amplo e completo. Diversos especialistas podem apresentar informações pertinentes sôbre aspectos diferentes do problema ou tópico.

\section{Aspectos negativos}

O preparo prévio pode levar a um excesso de detalhes desnecessários. Como sejam muitos oradores, a amplitude pode prejudicar a profundidade da análise. Muitas vêzes o auditório não adquiriu uma idéia completa do assunto podendo, pelo tempo tomado pelos oradores, ficar sem participação conveniente.

\section{Material mais adequado para Simpósio}

Coleta de dados, números, estatísticas e fatos concretos. Geralmente devem ser apresentados assuntos não sujeitos a controvésia.

Um Simpósio seria como que uma revisão sob forma de coletânea, entre especialistas. da situação e condição em que se encontra assunto ou problema determinado, até aquele momento.

\section{ANEXO 7}

\section{SEMINÁRIO}

\section{DEFINIÇÃO}

Um seminário constitui uma forma de trabalho conjunto destinado a coletar informações, experiências e fatos, à guisa de um inventário, para se chegar a um conhecimento global e total de 
uma matéria, assunto ou especialidade que precise da colaboração e assistência de um número grande de especialistas e especializações. Assim, deve exigir uma boa distribuição de tarefas quanto a pesquisas, certo número de reuniões complementares e reuniões plenárias para conjugar e estabelecer intercâmbio entre os diversos grupos.

\section{ORGANIZAÇÃO}

Assemelha-ì a uma Conferência sob certos pontos-de-vista. Contudo, a grande diferença é que "procura coletar e inventariar experiências e conhecimentos" adquiridos até um momento dado, "coordenando" tôdas as atividades, especializações, e resultados obtidos, chegando a conclusôes. As Associações, Repartições e Grupos que na vida prática se entreguem a atividades "correlatas ou ligadas" devem levar representantes ou delegados providos de documentação quanto a suas especializações. Daí decorre logo a necessidade da seguinte organização:

Comissão Executiva - Presidente

Secretaria Geral - Secretaria

Comissões Técnicas - (Setor, Seção, Assuntos ou Temas).

Cada grupo ou comissão organiza suas reuniões e elabora seus Relatórios que devem ser os mais completos. Nas sessões plenárias, sumariadas de acôrdo com as solicitações das comissões, serão lidas as "sinteses" dos Relatórios. A publicação tem que contar com a impressão total. Nas sessões sumárias podem existir debates e discussões, nas plenárias, contudo, a discussão constitui exceçãc.

No Seminário, cada qual e cada grupo ou associação leva o produto de seu estudo, pesquisas e experiências. Entre êles pode existir controvérsia, o que não deverá acontecer na sessão plenária.

\section{ASSUNTOS MAIS ADEQUADOS PARA SEMINÁRIO}

Os problemas gerais que exigem a participação e colaboração entre uma grande diversidade de especialidades e de atividades. Em nosso meio houve em 1954 (janeiro-fevereiro), na Universidade Rural, do Rio de Janeiro - GB, o "Seminário LatinoAmericano de: Bem-Estar Rural". Compareceram as Delegações e Comissões de vários paises e entidades oficiais. Houve muitos observadores que participaram espontâneamente demonstrando interêsse pelo assuntc ou por alguns dos temas focalizados. Todos os ossuntos gerais se prestam bem para seminários, para que se consiga uma coordenação de várias atividades convergindo para 
um objetivo comum. Os Relatórios, as Conclusões, as Recomendações e as Sugestões irão constituir valioso subsídio para o Planejamento Global.

\section{VANTAGENS}

A maior é o grande acervo que traz para os procedimentos futuros e os planejamentos, dado que ficam conhecidos as experiências, os desajustes, as dificuldades oriundas de deficiente entrosamento, coordenação, sinergia funcional e "unidade" entre grande número de atividades e ações que convergem para um objetivo comum. No mesmo passo, o intercâmbio das experiências diversificadas, obtidas em condições e conjunturas variadas, procurará reajustamentos e expansão dos serviços pelas "recomendações e sugestões".

\section{DESVANTAGENS}

$\mathrm{E}^{\prime}$ muito difícil conseguir organizar um seminário em bases amplas, justamente quando a sua eficácia se torna comprovada. Sem interêsse de autoridades em grande número, sem a participação de associações e entidades culturais, sem meios sufiicentes de divulgação dos resultados, o Seminário deixa de preencher a sua finalidade.

\section{OS CASOS MAIS SIMPLES}

Pode-se organizar um Seminário em condições mais práticas e bem mais restritc. Sob certos aspectos, resultados diferentes podem incentivar a retomada de pesquisas e estudos. Escolhe-se um Coordenador e vários Relatores sôbre diversos aspectos e pontos que possam atingir ov interessar ao Tema ou Assunto ou tese.

Cada Relator ficará encarregado de coletar e inventariar subsídios para elaborar um Relatório de 10 páginas. Pode haver vários relatores sôbre o mesmo ponto ou aspecto. O "Coordenador" por sua vez se mune de um relatório substancial próprio ou de autoria de grande autoridade acêrca do ponto ou aspecto referido. Inclusive tal Kelatório pode ser do próprio Tema. Guarda o mesmo consigo com reserva absoluta. Os relatórios devem contar tudo o que seja conveniente em uma sintese para chegar a uma conclusão. Marcada uma reunião para leitura e discussão dos relatórios, começam a delinear-se os campos de opinião, caso haja controvérsias. Esgotada a fase de discussões e conseguida ou não uma unanimidade será marcada a Reunião 
onde o Coordenador lerá e discutirá com os relatores as opiniões já firmadas, frente ao seu Relatório reservado para esta oportunidade. Serão ent Đo reajustadas as opiniões, mantidas outras, contrariadas algumas etc. Nesta ocasião será eleito o Relator Geral. Quando uma minoria ou um só membro discordar dos fundamentos terá êle que ser o Relator Geral da minoria ou de seu pontode-vista. Os dois Relatórios devem sempre ser impressos em um só volumie, cada qual com sua documentação e argumentação próprias. Se bem que uma sintese deva ser elaborada para uma leitura de 50 a 60 minutos. em plenário, o Relatório deverá ser completo na sua documentação. Os dois Relatórios discordantes devem ser lidos, sintèticamente, na reunião plenária.

Os trabalhos se passam como se objetivassem um "digesto" acêrca de Assunto ou 'Tema, entrando os relatórios parciais como exposição de aspectos, pontos-de-vista e inclinações de cada qual. $\mathrm{O}$ "conjunto" resultará em uma coletânea que obteria a colaboração de autoridade no assunto prèviamente escolhido pelo "Coordenaçor". A bibliografia é absolutamente necessária assim como as fontes informativas, selecionadas em "fichas de anotações", documentário indispensável do Relatório Geral.

\section{VANTAGENS}

A. facilidade de execução desta modalidade de Seminário permite a sua prática corrente nas universidades e centros de cultura geral. Mesmo uma questão científica ou técnica será beneficiada com êste processo, esclarecendo o campo para os Congressos, as Conferências e o Seminário de grande amplitude.

O "Coordenador" e os relatórios terão oportunidade de ficar profundametute informados sôbre a matéria, dado que deverão mostrar conhecimentos nas discussões. 


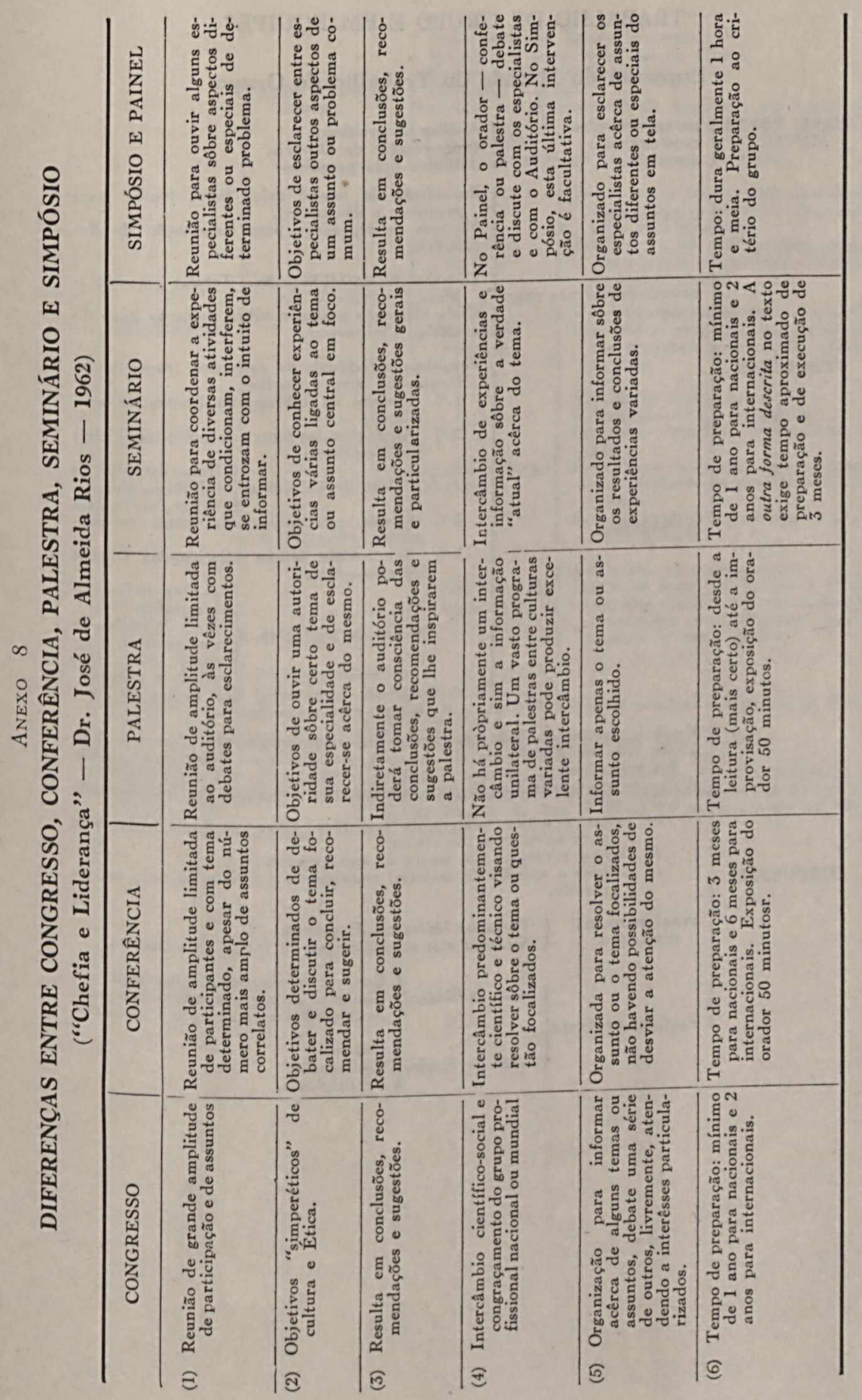




\section{"TRABALHO DE GRUPO E EM EQUIPE"}

\section{Esquema do Método do Trabalho de Grupo}
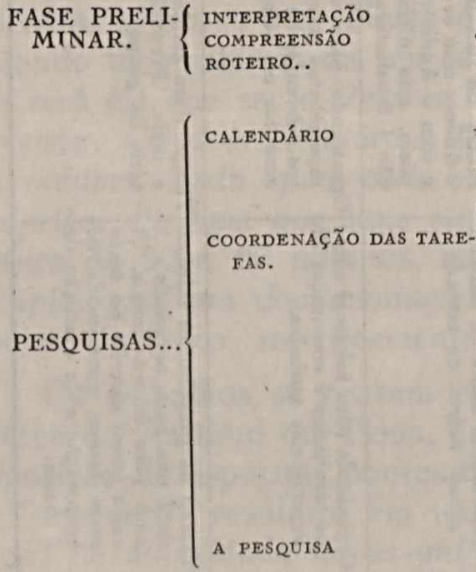

DISCUSSÃO. . dos trabalhos). o dirigente: parado.
(Análise do problema.

Interpretação da Diretriz.

Assuntos para pesquisas.

$\int$ Repartição do tempo pelas fases (maior para pesquisas e discussões).

Margem de segurança para terminação do Relatório.

Distribuição de bibliografia. Tarefas para assessôres.

Cada elemento pesquisa sôbre todos os itens do esbôço (Subtemas).

Pesquisas individuais ou coletivas, trocas de informaç̃es, orais e escritas:

1.0) Preparo da bibliografia (fontes de consultas);

2.0) Anotações das fontes de consultas (Fichas bibliográficas);

(Nome doautor, tíA ficha deverá conter tulo do documento, editor, local e data

3. ) Seleção qualitativa das fontes de consultas;

4.0) Estudo das fontes selecionadas (Fichas de anotações);

(N.o no índice bi-

Fichas de anotações... $\begin{aligned} & \text { bliográfico. } \\ & \text { Item do esbôço do }\end{aligned}$ que se trata e resumo, relato, capítulo e página.

5..$^{\circ}$ Estudo (por todos) das Fichas de Anotações e outras fontes.

Estabelecimento do Sumário (Provisório) para seguimento dos trabalhos. Designação ou Eleição do Relator (De preferência no decorrer adiantado

A discussão abrangerá sucessivamente todos os tópicos do sumário, devendo

a) obter o maior número de sugestões sôbre possíveis conclusões para soluções e discutí-las;

b) tentar conseguir um ponto de vista comum;

c) adotar a opinião da maioria, ressalvando o direito do voto em se-

FINALIDADE DA $\{$ Troca de idéias ou de opiniões.

Discuss̃̃o. $\quad$ Alcançar um entendiemtno ou tomar uma decisão.

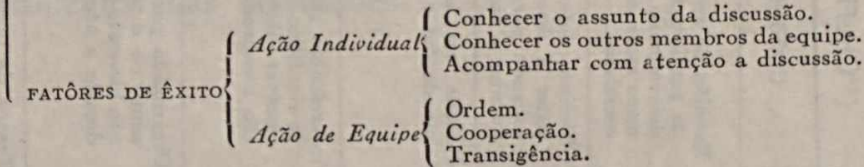




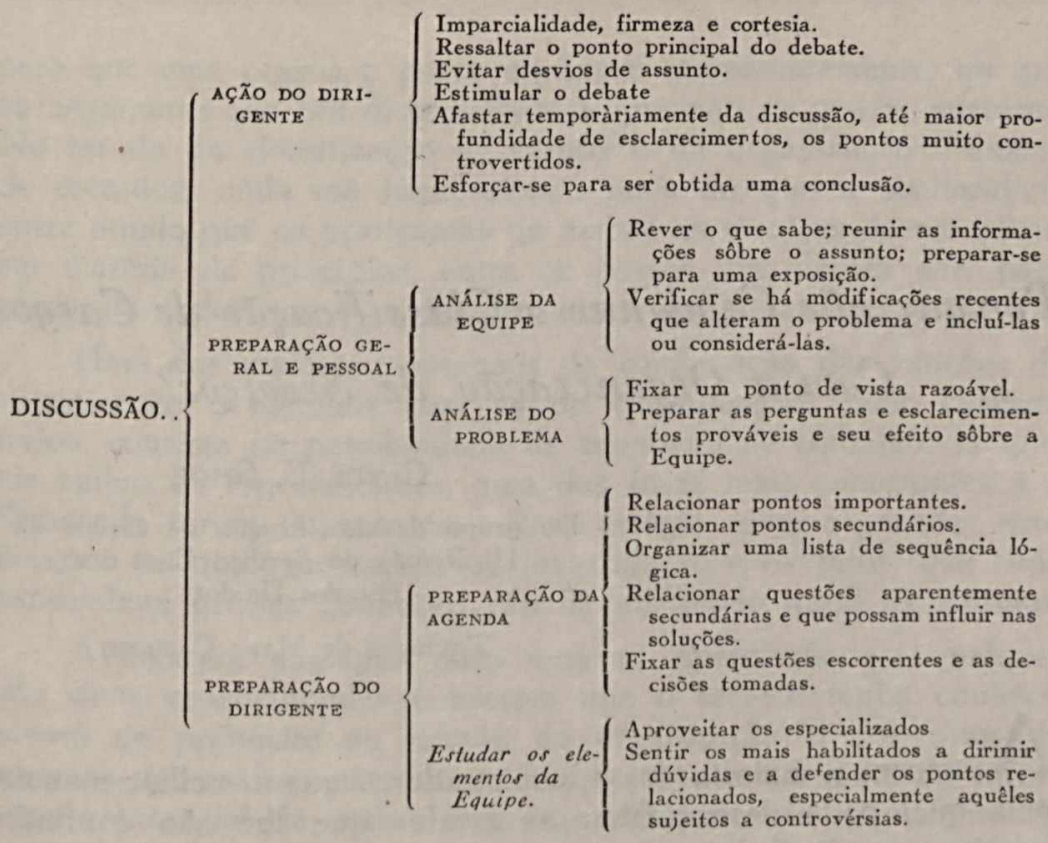
Sumário definitivo.
Redação do Relatório ou Monografia.
Redação do Relatório ou Monografia. grafia ou Tese ou Assunto.
O Relatório ou Monografia deve ser discutido, item por item.

PREPARO DA SÍNTESE DE Seleção dos assuntos essenciais do trabalho elaborado.

APRESENTAÇ̃̃O EM AU- Eesumo das partes correspondentes aos aspectos secundários DITÓRIO. 